Contemporary Herpetology

ISSN 1094-2246

2001 Number 5

31 December 2001

\title{
BIOGEOGRAPHY AND PATTERN VARIATION OF KINGSNAKES, LAMPROPELTIS GETULA, IN THE APALACHICOLA REGION OF FLORIDA
}

D. Bruce Means ${ }^{1}$ and Kenneth L. Krysko ${ }^{2}$

${ }^{1}$ Coastal Plains Institute and Land Conservancy, 1313 N. Duval Street, Tallahassee, FL 32303, USA

Corresponding author: (850) 681-6208, Fax: (850) 681-6123, E-mail:

means@bio.fsu.edu

${ }^{2}$ Florida Museum of Natural History, and Dept. Wildlife Ecology and Conservation, University of Florida, Gainesville, FL 32611, USA

Key words: Lampropeltis getula, Kingsnake, Systematics, Biogeography, Geographic Variation, Apalachicola, Florida

Abstract - Morphology of kingsnakes, Lampropeltis getula, is described and analyzed in the Apalachicola region of the Florida panhandle. Populations inhabiting the eastern Apalachicola Lowlands, a distinct biotic province, are different from the surrounding populations in having fewer and wider light body crossbands, distinct ontogenetic interband lightening, unique ventral patterns, and the presence of non-banded (striped and patternless) individuals. We conclude that the name L. g. goini as well as the hypothesis that Apalachicola $L$. getula are relict populations of intergrades between $L$. $g$. getula and $L$. g. floridana are invalid. We believe the polymorphic eastern Apalachicola Lowlands populations are most closely related to L. g. getula, and evolved in isolation on a barrier island or the coastal strand of a peninsula during one of the many higher stands of sea in the Pleistocene.

Kingsnakes, Lampropeltis getula (Linnaeus), display a wide variety of color patterns (7 subspecies, Blaney, 1977) over their extensive geographic range from Oregon to New Jersey and southward to Baja California, the Mexican Plateau, and Florida (Figure 1). In the eastern U. S. the nominate subspecies, L. g. getula, is distributed from southern New Jersey to northern Florida (Conant and Collins, 1998). Its dorsal pattern is solid black to chocolate brown with 19-32 light-colored and narrow (1.5-2.5 dorsal scale rows wide) body crossbands (Figure 2; Krysko, 1995; Tennant, 1997). In the Florida 
peninsula, $L$. g. floridana has a light yellow dorsal pattern with $>34$ light-colored and narrow ( 1.5 dorsal scale rows wide) crossbands (Figure 3 ). Both L. g. getula and L. g. floridana newborns have bold light-colored crossbands with black interbands (= interspaces between light crossbands). The light yellow dorsal pattern of adult $L$. $g$. floridana is derived from ontogenetic lightening of the normally black interbands.

Surrounded by L. g. getula is a small area called the eastern Apalachicola Lowlands, which has been recognized as an important center of endemism (Figure 1; Means, 1977). Here, L. getula differ dramatically from the surrounding populations in several respects, including the number and width of crossbands, normally dark dorsal interband scales that are ontogenetically lightened anteriorly, ventral pattern, and uniquely patterned non-banded individuals (Means, 1977, 1978; Krysko, 1995).

Over the years $L$. getula researchers have considered Apalachicola populations to be 1) a distinct subspecies called L. g. goini (Figure 4), occurring west of the Apalachicola River (see Figure 1 in Neill and Allen, 1949); 2) relict intergrades from the Pleistocene between L. g. getula and now disjunct peninsular Florida L. g. floridana (Blaney, 1977); and 3 ) intergrades between L. g. getula and unnamed populations from the Apalachicola Lowlands (Means, 1977; Krysko, 1995).

Based upon fieldwork since 1968 and morphological analyses, we test each of the above hypotheses. We then present our interpretation of the historical biogeography and evolutionary significance of these unique populations.

\section{MATERIALS AND METHODS}

The center of our study area exists in the Florida panhandle, bounded by the Choctawhatchee River on the west and the Aucilla River on the east (Figure 1). We divided the study area into three populations: 1) panhandle (areas 1-4), 2) western Apalachicola Lowlands on the west side of the Apalachicola River (area 6), and 3) eastern Apalachicola Lowlands on the east side of the Apalachicola River (area 6). To analyze morphological characters over a broader geographic range, we expanded our panhandle population to the west and east incorporating the entire range of $L$. $g$. getula in Florida (Krysko, 1995).

Morphological data were obtained from 321 wild-collected specimens (Appendix I). Morphological characters included crossband numbers and color pattern. Crossband numbers were counted from one head length posterior to the head to just above the cloaca. Crossband width was determined by the number of dorsal scale rows at midbody. Because non-banded individuals essentially have one crossband from head to tail tip (see justification in results), they were given a set value of 200 for crossband width in statistical analyses even though there are greater than 200 dorsal scale rows on the body of this species. The degree of ontogenetic lightening of the normally dark interband scales was rated on adults with a system of $A-F$, where interband scales have $A=$ no lightening typical of L. g. getula (Figure 5 ), B = up to $25 \%$ of the intensity of the crossbands typical of L. g. goini (our Figure 6 and Figures 1, 2, and 3 in Neill and Allen, 
1949), $C=25-75 \%$ of the intensity of the crossbands (Figure 7 ), and $D=75-100 \%$ of the intensity of the crossbands (Figure 8). Also, non-banded ( $\mathrm{E}=$ striped and $\mathrm{F}=$ patternless) individuals (Figure 9 and Figure 10, respectively) were scored as D.

Adults that possess interbands nearly the same intensity as crossbands appear to be non-banded. However, they can be distinguished from truly non-banded morphs on the basis of the difference in morphology between the light-colored crossband and interband scale types. Within a light crossband scale, light pigment is separated from dark pigment by a sharp, straight line; within a lightened interband scale, the edge of the light pigment is rounded, not straight (Figure 11).

A striped pattern was scored if the light pigment of the crossbands was aligned longitudinally rather than transversely along the body of the snake. Most often this was manifested as a solidly light-colored animal with a longitudinal, mid-dorsal faintly darker stripe from 1-3 dorsal scale rows wide (Figure 9). A patternless specimen was scored if the dorsal pattern was uniformly light-colored without distinct banding or striping (Figure 10). To such snakes we might have applied the term "speckled," but we chose not to because it is the common name of $L$. g. holbrooki Stejneger, a race found west of $L$. $g$. getula. Additionally, the morphological character states determining the speckling pattern in L. g. holbrooki are different from those in the Apalachicola region. Both the light band scales and interband scales are lightened basally for individuals in the Apalachicola region, and lightened in the center in L. g. holbrooki.

The ventral pattern was scored as 1) tight checkerboard typical of L. g. floridana (Figure 12), 2) loose checkerboard typical of L. g. getula (Figure 13), 3) bicolored (Figure 14), or 4) loose checkerboard with interspersed bicolor scales (Figure 14).

Statistical Analyses.-t-tests were performed to test for sexual dimorphism in crossband numbers and crossband width within each population. We used Analysis of Variance (ANOVA) to determine significance in mean crossband numbers and crossband width between each population and when significance was detected we used General Linear Models (PROC GLM) with Least Squares Means (LSM) as a multiple comparison tool. Analyses were conducted using Statistical Analysis System (SAS for windows, ver. 6.12).

\section{RESULTS}

Sexual Dimorphism.-There was a significant difference in crossband numbers $(\mathrm{P}=$ $0.0005)$ and crossband width $(P<0.0001)$ between males and females in only the eastern Apalachicola Lowlands population, due to a higher frequency of males possessing a non-banded phenotype. Of all the specimens we examined from the entire Apalachicola Lowlands, $38 \%(n=100)$ from the eastern and $7.5 \%(n=53)$ from the southwestern Apalachicola Lowlands were non-banded.

Geographic Variation.-There were significant differences in crossband numbers among all three populations (all $P$ values $<0.001$ ). The number of crossbands reaches its 
lowest value in the eastern Apalachicola Lowlands (mean $=11.5$, S.E. $=0.87$, range $=$ $1-24, \mathrm{n}=97$; Figure 15), followed by the western Apalachicola Lowlands (mean $=17.8$, S.E. $=0.85$, range $=1-24, n=45$ ) and panhandle (mean $=21.8$, S.E. $=0.26$, range $=$ $14-31, n=148)$.

There were significant differences in crossband width between all three populations (all $P$ values $<0.05)$. Crossband width reaches its highest value in the eastern Apalachicola Lowlands $($ mean $=77.4$, S.E. $=9.56$, range $=1.5-200, n=99$; Figure 16 ), followed by the western Apalachicola Lowlands (mean $=20.17$, S.E. $=7.74$, range $=1.5-200, n=$ 49 ) and panhandle (mean $=2.19$, S.E. $=0.10$, range $=1.5-8, n=162$ ).

The degree of interband lightening reaches its greatest expression in the eastern Apalachicola Lowlands (Figure 17). While raising neonates to adulthood, we noticed that all banded individuals have black interbands at hatching (Figure 18). Individuals centered on the eastern Apalachicola Lowlands undergo considerable ontogenetic interband lightening (Figure 19) similar to peninsular L. g. floridana (Krysko, 1995). Eighty-nine of $93(96 \%)$ adults from the eastern Apalachicola Lowlands showed interband lightening as $\mathrm{C}$ or D (Figure 7 and Figure 8 ). Only four (4\%) adults showed interband lightening as $\mathrm{B}$ (Figure 7 and Figure 8 ) and were peripheral to the Apalachicola Lowlands (Figure 17).

During embryonic development of individuals having $>15$ crossbands or crossbands $>$ 8 dorsal scale rows wide, the distinct crossbands break up and fuse in two basic ways forming non-banded (striped and patternless) phenotypes. First, the light crossbands fuse laterally and divide mid-dorsally producing a light-colored individual with a black mid-dorsal stripe (Figure 20). This stripe appears to be the remnants of the black interbands since it undergoes ontogenetic lightening. Second, the light crossbands fuse both dorsally and laterally, producing a patternless individual with essentially one crossband from head to tail tip (Figure 21). We might, therefore, be justified in considering that both striped and patternless individuals have one crossband whose width is the entire length of the snake. Non-banded striped and patternless snakes make up approximately $40 \%$ of the eastern Apalachicola Lowlands population and to date have only been found in the Apalachicola Lowlands (Figure 22).

Peninsular Florida L. g. floridana have a tight checkerboard ventral pattern (Figure 12). Lampropeltis g. getula from the panhandle have a loose checkerboard ventral pattern (Figure 13). Individuals from the Apalachicola Lowlands have ventral patterns consisting of a uniquely bicolored or a loose checkerboard with interspersed bicolored scales (Figure 14).

\section{DISCUSSION}

Geographic variation in crossband number (Figure 15), crossband width (Figure 16), and ventral pattern (Figure 12, Figure 13, and Figure 14) reaches its greatest levels of divergence in the eastern Apalachicola Lowlands. These character states illustrate that the eastern Apalachicola Lowlands population is morphologically distinct, and is 
most closely related to the western Apalachicola Lowlands in southern Gulf County. These two populations are most closely related to the surrounding populations of $L$. $g$. getula.

Neill and Allen (1949) named L. g. goini on the basis of nine specimens restricted to the Apalachicola and Chipola River valleys in Calhoun and in northern Gulf county on the western side of the Apalachicola River (Figure 1). Neill and Allen (1949:101) described L. g. goini as having 15-17 light crossbands of 4-8 dorsal scale-rows width with "vaguely" lightened interbands (= nearly black) that we rate as B (Figure 6 ) and a rich brown venter with alternating light streaks (see Figures 1, 2, and 3, Neill and Allen, 1949). They did not examine any snakes from the eastern Apalachicola Lowlands and their description did not include snakes with $<15$ crossbands, crossbands $>8$ dorsal scale rows wide, lightened interbands that we rated as C or D, non-banded phenotypes, nor bicolored ventral patterns. We examined an additional 76 specimens from Calhoun and northern Gulf counties that were similar in morphology to the type of L. g. goini. We consider the dark-patterned type of L. g. goini to be intermediate between $L$. $g$. getula and the light-colored, broad-banded and non-banded snakes in the eastern Apalachicola Lowlands. Because the morphology and locality of L. g. goini are intermediate between L. g. getula and snakes in the eastern Apalachicola Lowlands, we consider L. g. goini to be an invalid name.

If an intergrade population between L. g. getula and L. g. floridana exists in the Apalachicola region as speculated by Blaney (1977), individuals there should have intermediate character states between the two putative parent races, such as in those that occur within the recognized intergradation zone between the two races in northern peninsular Florida (Krysko, 1995). However, crossband number reaches its lowest value in the eastern Apalachicola Lowlands population, is intermediate between L. $g$. getula and L. g. floridana within their intergradation zone in northern peninsular Florida, and rises to its highest value in peninsular Florida within the geographic range of $L$. $g$. floridana (Krysko, 1995). Crossband width reaches its highest value in the eastern Apalachicola Lowlands, is intermediate between L. g. getula and L. g. floridana within their intergradation zone in northern peninsular Florida, and is invariably the lowest value of 1.5 dorsal scale rows wide in peninsular L. g. floridana (Krysko, 1995). Ventral patterns in the eastern Apalachicola Lowlands are more similar to L. g. getula, and strikingly different from peninsular L. g. floridana. The eastern Apalachicola Lowlands population displays no intermediacy in crossband numbers, crossband width, and ventral patterns between L. g. getula and L. g. floridana, rather it represents the extreme for each of these character states and appears to be more closely related to $L . g$. getula. Therefore, we believe that Blaney's (1977) hypothesis that the Apalachicola Lowlands populations are relict intergrades between L. g. getula and L. g. floridana is invalid.

Means (1977) hypothesized that L. g. goini from west of the Apalachicola River is intermediate between L. g. getula and an unnamed population occurring in the Apalachicola Lowlands. The eastern Apalachicola Lowlands population is distinct in having crossband numbers from 1 to 25 (mean $=11.5$ ), crossband width from 3 to 200 
(mean $=77.4)$ dorsal scale rows, lightened interbands rated as C and D, ventral patterns of bicolor or loose checkerboard with interspersed bicolor scales, and nonbanded (striped or patternless) morphs. Under the Apomorphic Species Concept (Phylogenetic Species Concept sensu Mishler and Theriot, 2000), we believe that the eastern Apalachicola Lowlands population represents an undescribed polymorphic taxon, morphologically distinct and worthy of taxonomic recognition.

The uniquely patterned eastern Apalachicola Lowlands kingsnakes are only one of many endemic and relict taxa having the same or similar geographic distributions there (Table 1; Harper, 1914; Neill, 1957; James, 1961; Means, 1978, 1992). The isolating mechanism allowing for the evolution of these snakes may be the same mechanism explaining the distribution of these endemics and relicts. Among the Apalachicola Lowlands endemics is another snake, the brown-chinned racer, Coluber constrictor helvigularis (Auffenberg, 1955). In addition, there are 15 species of endemic and relict plants that are found either strictly confined to, or geographically centered on, the region. The presence of so many narrowly restricted endemics and relicts occurring together suggests their ancestors must all have been isolated together in the past. The proximity of the Apalachicola Lowlands to the Gulf of Mexico, and the fact that extensive barrier islands have developed offshore in the past 6500 years (Stapor, 1975), suggests isolation might have been in the form of ancient islands or peninsulas created by high stands of the sea during the Pleistocene.

In fact, a pair of long, low, narrow, convex-seaward sand bodies lies about $30 \mathrm{~km}$ inland from the present seacoast, precisely in the middle of the eastern Apalachicola Lowlands (Figure 1). These elevated sand bodies have been postulated as ancient barrier islands lying offshore from a Pleistocene terrace during high stands of the sea (Brenneman, 1957; Brenneman and Tanner, 1958), and could have served as the isolated habitats allowing for the evolution of the Apalachicola Lowlands endemics.

For our barrier island hypothesis to be true, we must explain the occurrence of broadly crossbanded, striped, and patternless individuals in southern Gulf Co. west of the lower Apalachicola River. Like most large, low-gradient Coastal Plain rivers near their mouths, the Apalachicola River meanders across the landscape. When the post-Pleistocene Gulf of Mexico stabilized at its present level about 5,000-6,000 years ago, the Apalachicola River flowed into the Gulf of Mexico west of its present position (Donoghue, 1989). At that time its mouth was located at Cape San Blas, thus the present western Apalachicola Lowlands population was part of the eastern Apalachicola Lowlands. Subsequently, the lower Apalachicola River changed its course to the east, leaving the southern Gulf Co. population stranded on the west side of the Apalachicola River.

The selective advantage of a lightly pigmented snake in a coastal setting is obvious in a large, slow-moving, diurnal animal such as L. getula. Light-colored snakes would be less conspicuous against white sands to visually orienting predators. Also, light-colored patterns may have aided in thermoregulation by reducing the risk of overheating on the highly reflective white sands. The bright white sands of barrier islands and the coastal 
strand for which the Florida Gulf Coast is famous are also believed to have been responsible for the evolution of light-colored races of the oldfield mouse, Peromyscus polionotus (Bowen, 1968). We hypothesize that a similar ecological setting favored the selection of lightly pigmented $L$. getula against the white sands of some Pleistocene barrier island or peninsula, possibly the two ancient islands presently located $30 \mathrm{~km}$ inland near the ancient mouth of the Apalachicola River.

\section{ACKNOWLEDGMENTS}

We owe a special debt of thanks to numerous people who have assisted us in the field and collecting DORs in the Apalachicola drainage over the years: M. H. Floyd, G. H. Means, R. C. Means, L. E. Krysko, A. T. Reppas, W. W. Baker, O. G. Brock, K. L. Richmond, K. Studenroth, C. J. Longden, A. Meyer, C. R. LaBar, P. E. Moler, D. Martin, N. Hunter, K. M. Enge, J. A. Wilson, J. R. Tanner, R. Sokol, B. Griswold, W. G. Griswold, S. Cushnir, R. H. Robins, J. Roman, G. Lopresti, F. W. King, R. D. Bartlett and $A$. Tennant. Others who have shared information with us are W. Harrington, R. Funk, S. Hoffman, G. Lepera, C. May, K. McHugh, R. Douglas, H. M. Smith, W. Cope, M. Robertson, and D. Justice. O. G. Brock, D. Martin, and A. T. Reppas assisted us in laboratory measurements and photography. For assistance with museum specimens we thank F. W. King, D. L. Auth, D. Rossman, F. Burbrink, C. Guyer, R. Reed, and G. Schneider. We are grateful to P. Krafft and the Florida Resource and Environmental Analysis Center for help preparing Figure 6, 7, 8, and 11; Z. Mahfoud for help running ANOVAs on SAS. We thank J. Travis, P. E. Moler, D. R. Jackson, F. W. King, J. B. Slowinski and T. Taggart for reviewing this manuscript. This study was supported in part by Tall Timbers Research Station (1969-1983) and Coastal Plains Institute and Land Conservancy (1984-1998) to DBM, and the Central Florida, Volusia County, and Suncoast herpetological societies to K.L.K. Work with live animals for captive breedings was approved by the Institutional Animal Care and Use Committee (IACUC) permit (\#A187), and permit (\#2670) was provided by the U.S. Forest Service to collect snakes in the Apalachicola National Forest. Finally, we would like to pay a special thanks to the late Joseph B. Slowinski for his assistance and understanding in preparing this manuscript for publication.

\section{LITERATURE CITED}

AUFFENBERG, W.

1955. A reconsideration of the racer, Coluber constrictor, in the eastern United States. Tulane Studies in Zoology 2(6):89-155.

BLANEY, R. M.

1977. Systematics of the common kingsnake, Lampropeltis getulus (Linnaeus). Tulane Studies in Zoology and Botany 19: 47-104. BOWEN, W. W.

1968. Variation and evolution of Gulf Coast populations of beach mice (Peromyscus polionotus). Bulletin of the Florida State Museum, Biological Sciences 12: 1-91. 
BRENNEMAN, L.

1957. Preliminary sedimentary studies of certain sand bodies in the

Apalachicola delta. Unpublished M.S. Thesis. Florida State University,

Tallahassee. , and W. F. Tanner

1958. Possible abandoned barrier islands in panhandle

Florida. Journal of Sedimentology and Petrology 28: 342-344.

CONANT, R., AND J. T. COLLINS.

1998. A field guide to reptiles and amphibians of eastern and central

North America, 3rd Ed. Houghton Mifflin Co., Boston.

DONOGHUE, J. F.

1989. Sedimentary environments of the inner continental shelf, northeastern Gulf of Mexico: Transactions of the Gulf Coast Geological Society 39: 355-364.

HARPER, R. M.

1914. Geography and vegetation of northern Florida. Florida Bureau of Geological Survey Annual Report 6: 163-437.

JAMES, C. W.

1961. Endemism in Florida. Brittonia 13: 225-244.

KRYSKO, K. L.

1995. Resolution of the controversy regarding the taxonomy of the kingsnake, Lampropeltis getula, in southern Florida. Unpublished M.S. Thesis. Florida International University, Miami.

LEVITON, A. E., R. H. GIBBS, JR., E. HEAL, AND C. E. DAWSON.

1985. Standards in herpetology and ichthyology: part I. Standard symbolic codes for institutional resource collections in herpetology and ichthyology. Copeia 1985: 802-832.

MEANS, D. B.

1977. Aspects of the significance to terrestrial vertebrates of the Apalachicola River drainage basin, Florida. Pages 23-67 in Proceedings of the Conference on the Apalachicola Drainage System (R. J. Livingston and E. A. Joyce, eds). Florida Marine Research Publication 26.

1978. Rare: Apalachicola populations of the eastern common kingsnake including L. g. goini, Lampropeltis getulus (Linnaeus). Pages 60-61 in Rare and Endangered Biota of Florida. Volume III. Amphibians and Reptiles (P. E. Moler, ed). University Press of Florida, Gainesville. 1992. Rare: Eastern Common Kingsnake. Pages 232-236 in Rare and Endangered Biota of Florida. Volume III. Amphibians and Reptiles (P. E. Moler, ed). University Press of Florida, Gainesville. 
1998. Geographic distribution, Lampropeltis getula. Herpetological Review 29: 113.

MISHLER, B. D., AND E. THERIOT.

2000. The phylogenetic species concept sensu Mishler and Theriot: monophyly, apomorphy, and phylogenetic species concepts. Pages 4454 in Species Concepts and Phylogenetic Theory: A Debate (Q. D. Wheeler and R. Meier, eds). Columbia University Press.

NEILL, W. T.

1957. Historical biogeography of present-day Florida. Bulletin of the Florida State Museum, Biological Sciences 2: 175-220. , AND E. R. ALLEN.

1949. A new kingsnake (genus Lampropeltis) from

Florida. Herpetologica 5: 101-106.

SAS INSTITUTE INC.

1996. Release 6.12. SAS Institute Inc., Cary, North Carolina.

STAPOR, F. W., Jr.

1975. Holocene beach ridge plain development, northwest

Florida. Zeitschrift fur Geomorphologie 22: 116-144.

TENNANT, A.

1997. Field guide to the snakes of Florida. Gulf Publishing, Houston, Texas. 